\title{
PENGUAPAN AIR DAN PENYUSUTAN IRISAN UBI KAYU SELAMA PROSES PENGERINGAN MENGGUNAKAN MESIN CABINET DRYER
}

\author{
Water Vaporization and Shrinkage In Cassava ChipsDuring Drying Process Using $A$ \\ Cabinet Dryer Machine
}

\author{
Mima Purwanti1), Jamaluddin P. 2), Kadirman3) \\ ${ }^{1}$ Alumni Program Studi Pendidikan Teknologi Pertanian \\ ${ }^{2}$ dan ${ }^{3}$ Dosen PTP FT UNM \\ mimapurwanti@gmail.com
}

\begin{abstract}
ABSTRAK
Penelitian ini bertujuan untuk mengetahui mekanisme penguapan air dan penyusutan pada irisan ubi kayu selama pengeringan menggunakan mesin cabinet dryer.Irisan ubi kayu dikeringkan pada suhu 50,60, dan $70^{\circ} \mathrm{C}$ dengan waktu 240, 300, dan 360 menit. Parameter yang diamati adalah kadar air, laju penguapan dan penyusutan volume. Data penelitian ini dianalisis dengan menggunakan analisis deskriptif. Hasil penelitian menunjukkan bahwa selama proses pengeringan terjadi perubahan kadar air, laju penguapan dan penyusutan. Semakin tinggi suhu dan lama waktu pengeringan menyebabkan penurunan kadar air seiring dengan peningkatan penguapan air dan penyusutan.
\end{abstract}

Kata Kunci : Kadar air, Penguapan air, Penyusutan, Irisan ubi kayu, Pengeringan.

\section{ABSTRACT}

This research was aims to determine the mechanism of water vaporization and shrinkage in cassava chips during drying process using a cabinet dryer machine. Cassava chips driedat temperature 50,60, and $70^{\circ} \mathrm{C}$ with the time 240,300 , and 360 minutes. The parameter observed werewater content, water vaporization and shrinkage. The data were analyzed of descriptive. The results of the research showed that during drying process occurred of changes water content, water vaporization and shrinkage. More high the temperature and to the length of time drying cause decrease the water content with increase the rate water vaporization and shrinkage.

Keywords: Water content, Water vaporization, Shrinkage, Cassava chips, Dryin

\section{PENDAHULUAN}

Umbi-umbian merupakan bahan pangan potensial yang dapat mencukupi kebutuhan bahan pangan penduduk Indonesia salah satunya yaitu ubi kayu.Ubi kayu (Manihot esculenta) merupakan sumber bahan makanan kedua di Indonesia setelah padi.Sebagai sumber bahan makanan, ubi kayu dapat ditanam hampir di semua tempat karena tanaman ini tidak memerlukan banyak persyaratan tumbuh, sehingga pada tanah yang tandus ubi kayu masih dapat menghasilkan (Susilawati dkk, 2008).

Tingkat produksi tanaman ubi kayu yang besar ini menyebabkan harga ubi kayu dapat menurun pada masa panen raya dan memaksa petani menjual dengan harga yang rendah atau membiarkan tanamanannya membusuk di kebun karena ongkos panen lebih 
tinggi dari harga jualnya. Ubi kayu yang langsung dipasarkan setelah dipanen dan dikonsumsi secara langsung tanpa melalui proses pengolahan terlebih dahulu nilai gizinya masih sangat rendah dan daya tahan serta umur dari ubi kayu tersebut tidak lama (Muchlis $d k k, 2013$ ).

$$
\text { Ubi kayu mempunyai }
$$

kelemahan, antara lain menempati ruang yang besar dan memiliki kandungan air yang tinggi $(40-70 \%)$ sehingga mudah rusak/tidak tahan simpan, karena selama tiga hari dalam suhu ruang mutu ubi sudah menurun. Untuk mengatasi hal ini, perlu adanya suatu proses untuk mengolah bahan mentah tersebut menjadi bahan lain yang lebih tinggi daya gunanya maupun nilai ekonominya (Eka $d k k, 2006$ ).

Ubi kayu memiliki kadar air yang tinggi sehingga diperlukan proses pengeringan. Kadar air tersebut apabila masih tersimpan dan tidak dihilangkan, maka dapat mempengaruhi kondisi fisik bahan pangan.Keterlambatan proses pengeringan dapat menyebabkan kerusakan pada ubi kayu sehingga kualitasnya dapat menurun. Kerusakan terjadi akibat dari penyerapan enzim yang terdapat dalam bahan pangan oleh jasad renik yang tumbuh dan berkembang biak dengan bantuan media kadar air dalam bahan pangan tersebut. Mikroorganisme membutuhkan air untuk pertumbuhan dan perkembangbiakannya. Jika kadar air pangan dikurangi, pertumbuhan mikroorganisme akan diperlambat (Ana, 2012).

Metode pengeringan dapat
dilakukan dengan cara tradisional
maupun modern. Adapun metode
pengeringan dengan cara tradisional
yaitu dengan menggunakan sinar
matahari. Proses pengeringan di bawah
sinar matahari memerlukan waktu $4-5$ hari di musim kemarau namun saat musim penghujan waktu pengeringan bisa lebih lama. Selain itu, cara konvensional untuk pengeringan masih kurang efisien karena memerlukan media yang luas dan mutu hasil pengeringan relatif rendah dan tidak seragam (Muchlis $d k k, 2013$ ).

Salama proses pengeringan berlangsung terjadi proses penguapan air ke udara karena adanya perbedaan kandungan uap air antara udara yang terdapat dalam ruang pengering dan udara yang ada di dalam bahan yang dikeringkan. Laju pemindahan kandungan air dari bahan akan menyebabkan berkurangnya kadar air dan bahan yang dikeringkan. Selain kandungan kadar air yang berkurang setelah proses pengeringan maka bahan tersebut akan mengalami penyusutan yaitu dimana terjadi perubahan volume atau bentuk dari bahan tersebut. Perubahan volume bahan sangat menguntungkan karena bahan menjadi lebih kecil sehingga mempermudah dan menghemat ruang pengangkutan dan pengepakan, berat bahan menjadi berkurang sehingga mempermudah transport, dengan demikian diharapkan biaya produksi lebih murah (Suismono dalam Martunis, 2012). Hampir semua model pengeringan tidak mempertimbangkan penyusutan sebagai salah satu faktor yang sangat berpengaruh selama pengeringan berlangsung.Pada kenyataannya penyusutan tersebut pasti terjadi.Untuk itu perlu diamati perubahan bentuk dan ukuran yang terjadi, baik itu pengkerutan ataupun pembengkokan serta melihat hubungannya terhadap karakteristik pengeringan bahan yang dikeringkan.

Berdasarkan permasalahan tersebut maka diperlukan adanya suatu upaya pengembangan teknologi yang 
efisien, efektif serta tepat guna dalam pengeringan.Cabinet dryer merupakan alat pengering mekanis yang memanfaatkan penguapan energi panas. Beberapa keuntungan alat pengering cabinet dryer yaitu tidak banyak membutuhkan tenaga kerja manusia, irisan ubi kayu lebih bersih dan higienis karena kemungkinan adanya kotoran hewan, debu, kerikil, dan sampah lainnya lebih kecil, tidak dibutuhkan area yang luas serta suhu dan laju pengeringan dapat dikendalikan. Dengan demikian peneliti berinisiatif untuk melakukan penelitian tentang pengeringan menggunakan energi panas sebagai media penghantar panas dengan mengambil judul penguapan air dan penyusutan ubi kayu selama dalam proses pengeringan menggunakan cabinet dryer.

\section{TUJUAN PENELITIAN}

Penelitian ini bertujuan untuk mengetahui mekanisme penguapan air pada irisan ubi kayu selama pengeringan menggunakan mesin cabinet dryer dan mengetahui mekanisme penyusutan pada irisan ubi kayu selama pengeringan menggunakan mesin cabinet dryer.

\section{METODE PENELITIAN}

Jenis penelitian ini adalah penelitian eksperimen yang terdiri atas 2 faktor. Faktor $A$ adalah suhu dengan 3 taraf $\left(50,60\right.$ dan $\left.70^{\circ} \mathrm{C}\right)$ dan Faktor $B$ adalah lama pengeringan dengan 3taraf (240, 300, dan 360 menit). Dengan demikian banyaknya perlakuan yang dicobakan ada sebanyak 12 kombinasi perlakuan. Setiap kombinasi perlakuan diulang sebanyak 3 kali.

Peralatan yang digunakan dalam penelitian ini yaitu; mesin cabinet dryer, pisau, slicer, kompor gas, jam, Loyang, cawan, oven, timbangan analitik, desikator. Bahan yang digunakan yaitu; ubi kayu, air, dan gas LPG.

Prosedur yang dilakukan dalam penelitian ini yaitu sebelum melaksanakan penelitian dilakukan persiapan alat dan bahan yang akan digunakan dalam penelitian. Pengupasan ubi kayu, pemotongan ubi kayu dengan ketebalan $2 \mathrm{~mm}$, pencucian irisan ubi kayu, ubi kayu dikeringkan. Setelah proses pengeringan ubi kayu dikeluarkan dari mesin pengering kemudian didinginkan dan dilakukan pengukuran kadar air irisan ubi kayu. Langkah terakhir yaitu perhitungan penguapan air dan penyusutan volume ubi kayu dengan pendekatan persamaan:

1. Penguapan air

Laju penguapan air

$$
=\frac{\text { massa air yang diuapkan }}{\text { waktu pengeringan }}
$$

2. Penyusutan volume

Volume $=\frac{\mathrm{V} 1-\mathrm{V} 2}{\mathrm{~V} 1} \mathrm{X} 100 \%$

Dimana :

$V_{1}=$ volume pasir pada wadah berisi

irisan ubi kayu basah

$\mathrm{V}_{2}=$ volume pasir pada wadah berisi irisan ubi kayu kering.

\section{HASIL DAN PEMBAHASAN}

\section{Kadar Air Irisan Ubi Kayu}

Penurunan kadar air irisan ubi kayu dipengaruhi oleh suhu dan lama pengeringan yang digunakan. Semakin tinggi suhu maka penurunan kadar air akan semakin tinggi.

Hasil perhitungan kadar air irisan ubi kayu yang tertinggi adalah pada perlakuan suhu $50^{\circ} \mathrm{C}$ dengan lama pengeringan 240 menit dengan rata-rata $14.72 \%$ sehingga dapat dihitung perubahan kadar air sebelum dan setelah pengeringan yaitu $49.71 \%$, 
sedangkan kadar air terendah adalah perlakuan suhu $70^{\circ} \mathrm{C}$ dan lama pengeringan 360 menit dengan diperoleh rata-rata $7.04 \%$, sehingga dapat dihitung perubahan kadar air sebelum dan sesudah pengeringan yaitu sebesar $57.39 \%$

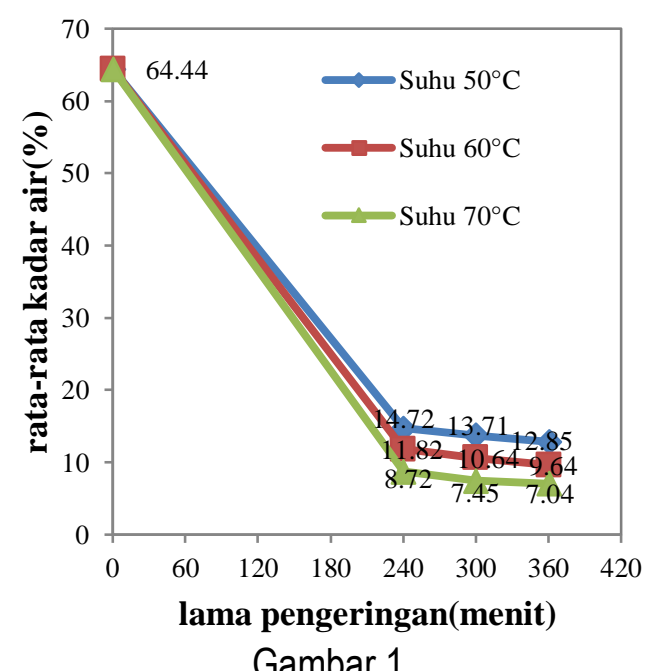

Hasil perhitungan kadar air irisan ubi kayu.

Hasil pengukuran kadar air dapat dilihat pada Gambar 1. Dari Gambar tersebut tampak bahwa pada awal pengeringan, mula-mula pada waktu 0-240 menit pada berbagai perlakuan suhu penurunan kadar air terjadi sangat cepat, sedangkan pada waktu 240-360 menit pada berbagai perlakuan suhu penurunan kadar air cenderung melambat. Penurunan kadar air irisan ubi kayu dipengaruhi oleh suhu dan lama pengeringan. Semakin tinggi suhu dan semakin lama pengeringan maka penurunan kadar air semakin tinggi. Hal tersebut dikarenakan semakin tinggi suhu pengering maka semakin besar energi panas yang yang dibawa udara sehingga semakin banyak jumlah massa cairan yang diuapkan dari permukaan bahan yang diuapkan.

Hasil penelitian ini menunjukkan bahwa pada irisan ubi kayu yang telah dikeringkan pada suhu 50 dan $60^{\circ} \mathrm{C}$ telah memenuhi standar mutu dalam pembuatan tepung yaitu $8-14 \%$, Namun irisan ubi kayu yang dikeringkan pada suhu $70^{\circ} \mathrm{C}$ tidak memenuhi standar mutu karena kadar air irisan ubi kayu yaitu $8 \%$ ke bawah. Adapun syarat dalam pembuatan tepung ubi kayu harus sesuai dengan SNI 01-2905-1992 bahwa kadar air gaplek dibawah 14\% (BSN,1992). Selain itu menurut Varian dan Engkos (2014) menyatakan bahwa untuk menghindari pembusukan atau penjamuran, kadar air pada ubi kayu perlu dihilangkan hingga tersisa 8-14\%.

Berdasarkan Gambar 1 tampak bahwa semakin lama proses pengeringan maka kadar air semakin sedikit atau rendah, karena pada saat pengeringan kadar air akan turun semakin cepat karena suhu semakin tinggi dan kecepatan aliran udara pengering semakin cepat akan mengakibatkan proses pengeringan semakin cepat. Semakin tinggi suhu udara pengering semakin besar energi panas yang dibawa udara, sehingga jumlah massa cairan yang diuapkan dari permukaan dari bahan yang dikeringkan. Hal ini didukung dengan pernyataan Muchtadi (1997) dalam Martunis (2012) menunjukkan bahwa proses pengeringan sangat dipengaruhi oleh suhu dan lama pengeringan. Selain itu Joko $d k k$. (2012) juga menyatakan bahwa semakin tinggi suhu udara yang digunakan untuk pengeringan, maka penurunan kadar air bahan juga akan semakin besar, sehingga waktu yang dibutuhkan untuk pengeringan akan menjadi semakin cepat. Hal ini disebabkan karena, semakin tinggi suhu udara pengering yang diberikan, maka perbedaan tekanan uap antara udara dengan tekanan uap pada bahan akan semakin besar. Dengan demikian, proses perpindahan uap air dari dalam bahan menuju udara sekeliling akan menjadi lebih cepat.

Bila suatu bahan pangan diletaktan dalam suatu ruang yang bersuhu dan tekanan tertentu maka akan terjadi penyerapan atau penguapan air sampai tekanan uap dalam bahan pangan sama dengan tekanan uap air udara 
lingkungannya. Pada saat pengeringan dimulai, uap panas dialirkan melalui permukaan bahan sehingga akan menaikkan tekanan uap air pada daerah permukaan sejalan dengan kenaikan suhunya. Pada saat proses ini terjadi, perpindahan massa dari bahan ke udara dalam bentuk uap air berlangsung atau terjadi pengeringan pada permukaan bahan. Setelah itu tekanan uap air pada permukaan bahan akan menurun. Setelah kenaikan suhu terjadi pada seluruh bagian bahan, maka terjadi pergerakan air dari bahan ke permukaannya. Akhirnya setelah air bahan berkurang, tekanan uap air bahan akan menurun sampai terjadi keseimbangan dengan udara sekitarnya.

\section{Laju Penguapan Air Irisan Ubi Kayu}

Jumlah air yang teruapkan pada irisanubi kayu dihitung berdasarkan selisih massa air mula berdasarkan perubahan kadar airirisanubi kayu. Berdasarkan hasil perhitungan laju penguapan air irisan ubi kayu, yang terendah adalah pada perlakuan suhu $50^{\circ} \mathrm{C}$ dengan lama pengeringan 360 menit dengan nilai rata-rata 0.1151 $\mathrm{g} /$ menit sedangkan yang tertinggi pada perlakuan $70^{\circ} \mathrm{C}$ dengan lama pengeringan 240 menit dengan nilai ratarata $0.178 \mathrm{~g} / \mathrm{menit}$.

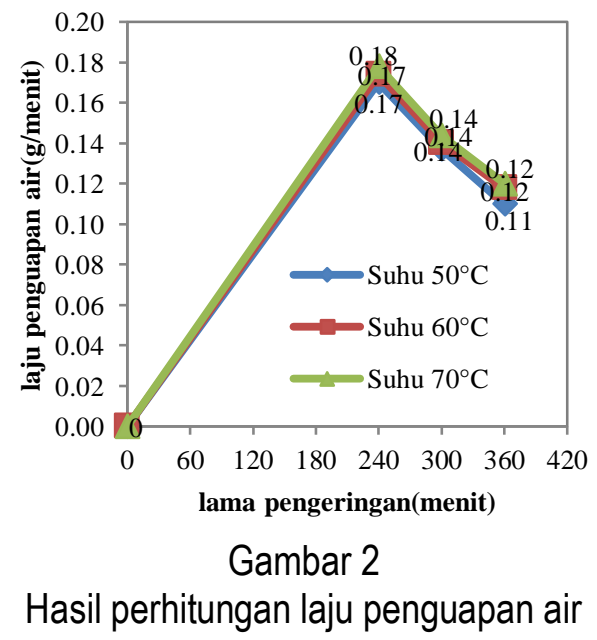

Berdasarkan Gambar 2 tampak bahwa pada awal pengeringan pada waktu 0-240 menit dengan berbagai perlakuan suhu proses penguapan air tejadi sangat cepat namun pada tahap selanjutnya mengalami penurunan. Hal ini disebabkan karena pada awal proses pengeringan akan terjadi penguapan kandungan air di permukaan irisan ubi kayu, pada tahap selanjutnya proses penguapan mulai melambat karena jumlah kadar air yang terkandung di dalam irisan ubi kayu semakin sedikit sehingga proses penguapan air akan melambat.

Berdasarkan Gambar 2 tampak bahwa semakin lama proses pengeringan maka laju penguapan akan semakin kecil atau melambat, pada proses pengeringan akhir kadar air irisan ubi kayu sudah semakin sedikit sehingga proses penguapannya akan semakin melambat. Hal ini didukung dengan pernyataan Noordin (2011) menunjukkan bahwa laju pengeringan sebanding dengan perbedaan tekanan uap antara bagian dalam dan bagian luar bahan, pada laju pengeringan konstan perbedaan tekanan uapnya juga konstan, tetapi dengan adanya penguapan maka uap di dalam bahan semakin rendah, oleh karena itu laju pengeringannya semakin menurun.

Berdasarkan hasil perhitungan laju penguapan air dapat diketahui bahwa semakin tinggi suhu pengeringan menyebabkan laju penguapan air semakin besar, hal ini dikarena suhu yang tinggi menyebabkan cepatnya panas merambat ke permukaan bahan yang dikeringkan sehingga akan menguapkan air di dalam bahan. Penurunan kadar air menjelaskan bahwa air dalam bahan masihberpotensi untuk mengalami penguapanselama periode akhir pengeringan. Hal tersebut terjadi 
sebab selamaproses pengeringan, selain adanya air bebasyang cenderung lebih pengeringan, adapula airterikat yaitu air yang sulit untuk bergeraknaik ke permukaan bahan selamapengeringan sehingga laju pengeringansemakin lama pengeringan maka semakin menurun (Bambang dkk., 2015).

\section{Penyusutan Volume Irisan Ubi Kayu}

Hasil perhitungan volume irisan ubi kayu menunjukkan bahwa setiap perlakuan suhu dan lama pengeringan yang diberikan akan menghasilkan volume irisan ubi kayu yang berbedabeda pada setiap perlakuan. Berdasarkan Gambar 3 terlihat bahwa irisan ubi kayu yang mengalami penyusutan volume terbesar adalah pada perlakuan suhu $70^{\circ} \mathrm{C}$ dan lama pengeringan 360 menit, dengan nilai rata-rata $0.80 \%$ sedangkan irisan ubi kayu yang mengalami penyusutan volume terkecil adalah pada perlakuan suhu $50^{\circ} \mathrm{C}$ dan lama pengeringan 240 menit dengan nilai rata-rata $0.33 \%$.

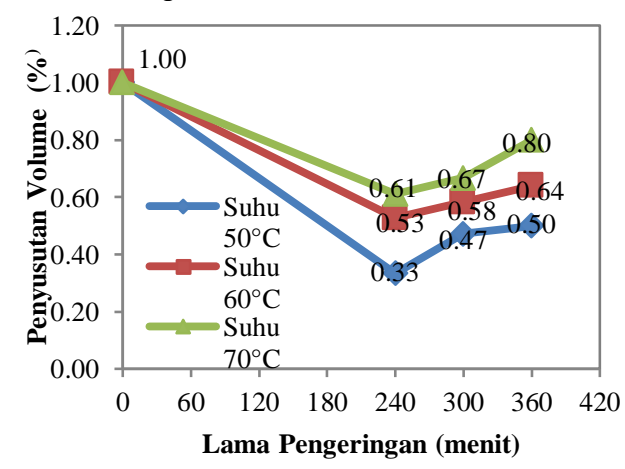

Gambar 3

Hasil perhitungan penyusutan irisan ubi kayu

Selama pengeringan, irisan ubi kayu mengalami penyusutan. Mula-mula pada waktu 0-240 menit dengan berbagai perlakuan suhu mengalami proses penyusutan yang cepat, sedangkan pada waktu 240-360 menit mudah menguap selama periode awal proses penyusutan irisan ubi kayu yang semakin meningkat. Berdasarkan hasil perhitungan penyusutan volume irisan ubi kayu yang terjadi selama proses pengeringan dapat disimpulkan bahwa suhu dan lama pengeringan akan berpengaruh terhadap penyusutan volume, semakin tinggi suhu dan semakin lama pengeringan menyebabkan penyusutan irisan ubi kayu akan semakin besar, hal ini diduga karena dengan suhu yang tinggi maka irisan ubi kayu akan cepat kering sehingga volumenya mengalami penyusutan.

Berdasarkan Gambar 3 tampak bahwa penyusutan volume irisan ubi kayu dipengaruhi oleh suhu dan lama pengeringan, semakin tinggi suhu dan semakin lama pengeringan maka mengalami penyusutan yang semakin besar. Dari gambar tampak bahwa pada awal proses pengeringan irisan ubi kayu mengalami penyusutan volume yang kecil pada tahap selanjutkan penyusutan ubi kayu mulai besar. Hal ini disebabkan karena pada awal proses pengeringan penguapan air yang terjadi pada irisan ubi kayu juga kecil, semakin tinggi suhu dan lama pengeringan menyebabkan uap air yang menguap semakin besar sehingga penyusutan irisan ubi kayu juga semakin besar. Hal ini sesuai dengan pernyataan Inge, $d k k$ (2010) menunjukkan bahwa penyusutan pada bahan selama pengeringan terjadi karena terjadi penguapan air selama proses pengeringan, bersamaan dengan terjadinya perubahan volume pada bahan. 
4. Keterkaitan kadar air dengan laju penguapan air irisan ubi kayu dengan berbagai perlakuan suhu $\left(50,60\right.$ dan $\left.70^{\circ} \mathrm{C}\right)$
Keterkaitan antara kadar air dengan laju penguapan air irisan ubi kayu dengan berbagai perlakuan suhu $\left(50,60\right.$ dan $\left.70^{\circ} \mathrm{C}\right)$ dapat dilihat pada Gambar berikut
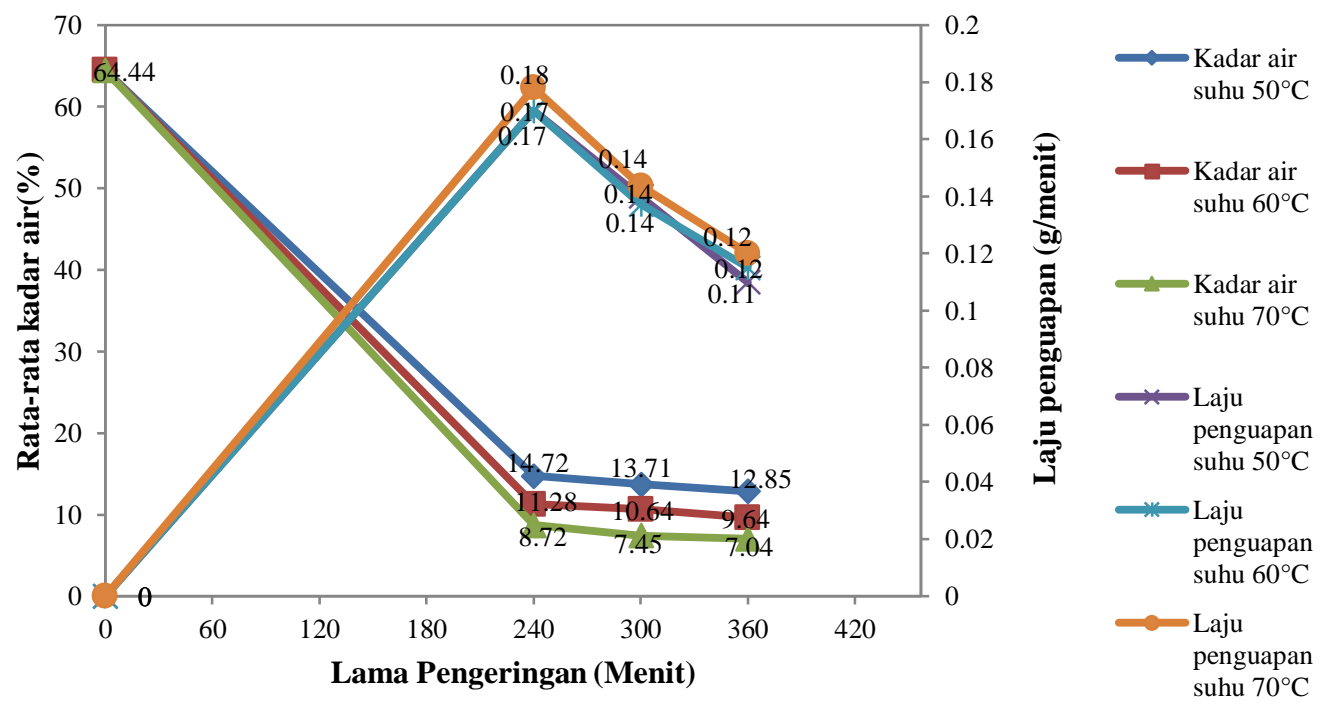

Gambar 4

Keterkaitan Antara Kadar Air dengan Laju Penguapan Air Irisan Ubi Kayu

Berdasarkan Gambar 4 tampak bahwa terjadi interaksi antara kadar air dengan laju penguapan irisan ubi kayu. Selama proses pengeringan terjadi penguapan air yang menyebabkan penurunan jumlah kadar air yang terdapat di dalam irisan ubi kayu. Semakin tinggi suhu pengeringan maka menyebabkan laju penguapan air semakin cepat sehingga kandungan air pada irisan ubi kayu semakin sedikit.

Berdasarkan Gambar 4 tampak bahwa terjadi interaksi antara kadar air dengan laju penguapan irisan ubi kayu. Selama proses pengeringan terjadi penguapan air yang menyebabkan penurunan jumlah kadar air yang terdapat di dalam irisan ubi kayu. Semakin tinggi suhu pengeringan maka menyebabkan laju penguapan air semakin cepat sehingga kandungan air pada irisan ubi kayu semakin sedikit. Hal ini sesuai dengan pernyataan Suriadi dan Made (2011) menyatakan bahwa dengan kondisi udara yang panas mampu menyerap air tersebut sampai kering dalam waktu yang lebih singkat.

Semakin lama proses pengeringan menyebabkan laju penguapan air irisan ubi kayu semakin melambat, karena kandungan kadar air yang terdapat di dalam irisan ubi kayu semakin sedikit. Hal tersebut terjadi sebab selamaproses pengeringan, selain adanya air bebasyang cenderung lebih mudah menguapselama periode awal pengeringan, adapula airterikat yaitu air yang sulit untuk bergeraknaik ke permukaan bahan selamapengeringan sehingga laju pengeringansemakin lama pengeringan maka semakin menurun (Bambang dkk., 2015). 
5. Keterkaitan kadar air dengan penyusutan volume irisan ubi kayu dengan berbagai perlakuan suhu $\left(50,60\right.$, dan $\left.70^{\circ} \mathrm{C}\right)$.
Keterkaitan antara kadar air dengan penyusutan volume irisan ubi kayu dengan berbagai perlakuan suhu $\left(50,60\right.$ dan $\left.70^{\circ} \mathrm{C}\right)$ dapat dilihat pada Gambar berikut:
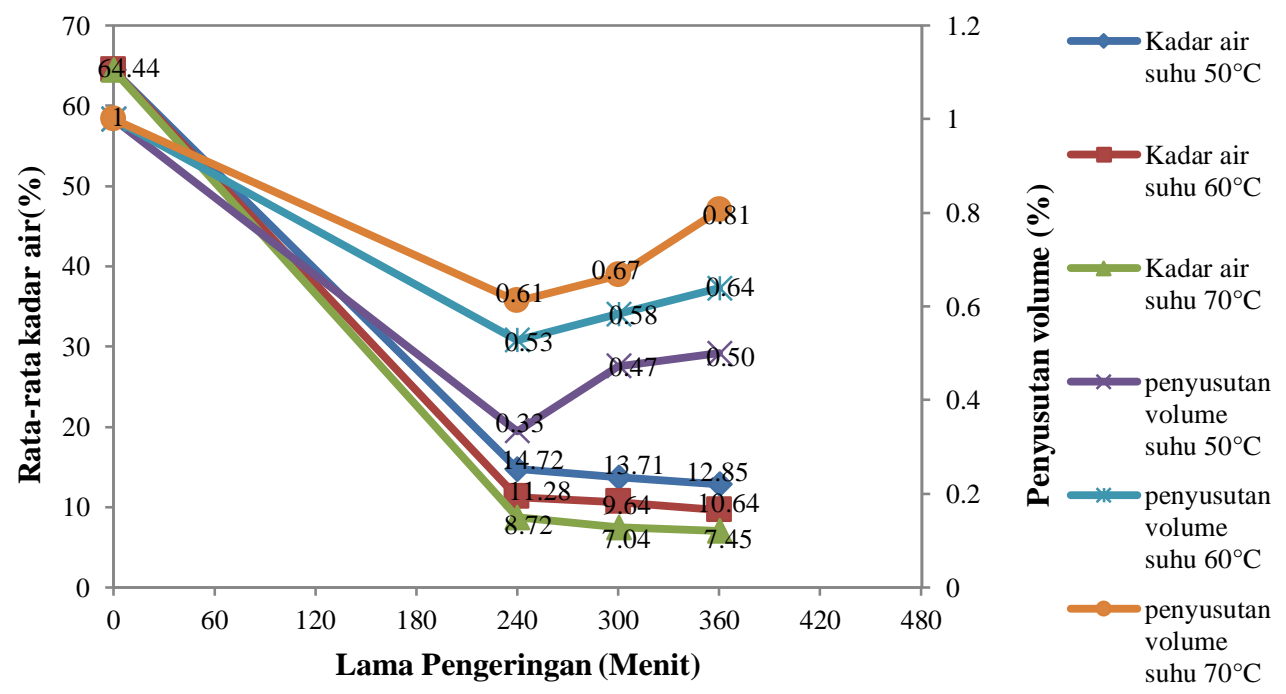

Gambar 5

Keterkaitan Antara Kadar Air dengan Penyusutan Volume Irisan Ubi Kayu

Berdasarkan Gambar 5 tampak bahwa terjadi interaksi antara kadar air dan penyusutan volume irisan ubi kayu. Selama proses pengeringan terjadi penurunan kadar air dan peningkatan jumlah penyusutan volume irisan ubi kayu. Pada awal pengeringan kadar air yang terkandung di dalam irisan ubi kayu masih banyak sehingga penyusutan volume hanya sedikit/kecil. Semakin lama proses pengeringan menyebabkan kadar air yang terkandung di dalam irisan ubi kayu berkurang/semakin sedikit sehingga menyebabkan penyusutan volume pada ubi kayu semakin besar.

Berdasarkan Gambar 5 tampak bahwa terjadi interaksi antara kadar air dan penyusutan volume irisan ubi kayu. Selama proses pengeringan terjadi penurunan kadar air dan peningkatan jumlah penyusutan volume irisan ubi kayu. Pada awal pengeringan kadar air yang terkandung di dalam irisan ubi kayu masih banyak sehingga penyusutan volume hanya sedikit/kecil. Semakin lama proses pengeringan menyebabkan kadar air yang terkandung di dalam irisan ubi kayu berkurang/semakin sedikit sehingga menyebabkan penyusutan volume pada ubi kayu semakin besar. Hal ini sesuai dengan pernyataan Inge, dkk (2010) menunjukkan bahwa penyusutan pada bahan selama pengeringan terjadi karena terjadi penguapan air selama proses pengeringan, bersamaan dengan terjadinya perubahan volume pada bahan.Penyusutan diduga disebabkan oleh penguapan air dari irisan ubi kayu hal ini sesuai dengan penyataan Jamaluddin $d k k$ (2011) menyatakan bahwa penyusutan disebabkan oleh penguapan air bebas dari dalam padatan yang terjadi karena adanya perbedaan 
tekanan di dalam dan pada permukaan padatan.Selain itu menurut Yadollahinia dan Jahangiri (2009) menunjukkan bahwa penyusutan meningkat sejalan dengan menurunnya kadar air bahan.

\section{KESIMPULAN}

Berdasarkan hasil penelitian yang dilakukan, maka dapat disimpulkan bahwa

1. Mekanisme penguapan air irisan ubi kayu selama pengeringan yaitu terjadi perubahan temperatur dari yang tinggi ke temperatur yang lebih rendah yaitu dari temperatur ruang pengering masuk kedalam irisan ubi kayu, hal ini meyebabkan perubahan kadar air irisan ubi kayu, semakin tinggi suhu dan lama proses pengeringan maka akan menghasilkan kadar air irisan ubi kayu yang rendah, serta suhu dan lama pengeringan akan berpengaruh terhadap laju penguapan air irisan ubi kayu, semakin tinggi suhu akan menyebabkan laju penguapan air yang semakin cepat dan semakin lama proses pengeringan maka akan menyebabkan laju penguapan air semakin kecil atau melambat, karena pada proses pengeringan kandungan kadar air dalam irisan ubi kayu sudah mencapai pada kadar air minimum.

2. Mekanisme penyusutan atau perubahan volume pada irisan ubi kayu selama pengeringan yaitu terjadinya perubahan bentuk pada irisan ubi kayu hal ini dipengaruhi oleh perubahan kandungan kadar air pada irisan ubi kayu, semakin tinggi suhu dan lama proses pengeringan menyebabkan penyusutan volume irisan ubi kayu semakin irisan besar.

\section{DAFTAR PUSTAKA}

Ana, Nurhasanah. 2012. Pengembangan Mesin Pengering Mocaf. Wonogiri. Diakses 18 April 2016.

Badan Standarisasi Nasional. 1992. SNI 01-2905- 1992: Gaplek. Jakarta: BSN. Diakses 19 Januari 2017.

Bambang, S. A., Godras, J.M., dan ratri. R.P. 2015.Kinetika pengeringan Chips sukun (Artocarpus Communis) dalam Pembuatan Tepung Sukun Termodifikasi dengan Asam Laktat menggunakan Cabinet Dryer. Universitas Sebelas Maret. Jurnal Teknologi Hasil Pertanian, Vol.III, No 1. Diakses 9 Desesmber 2016.

Eka, L., Merynda Indriyani Syafutri, dan Friska Syaiful. 2006. Pengaruh Perbedaan Suhu Pengeringan Tepung Tapai Ubi Kayu Terhadap Mutu Fisik Dan Kimia Yang Dihasilkan. Universitas Sriwijaya Indralaya. Jurnal ilmuilmu pertanian Indonesia volume 8, no 2, 2006, hlm 141-146. Diakses 18 April 2016.

Inge Scorpi Tuliza, Armansyah $\mathrm{H}$. Tambunan Dan Usman Ahmad.2010.Penyusutan Temu Putih (Curcuma Zedoaria (Berg) Roscoe) Terhadap Karakteristik Pengeringan Lapisan Tipis.Jurnal Keteknikan Pertanian Vol.24, No.2.Diakses 25 Agustus 2016.

Jamaluddin, Budi Rahardjo, Pudji Hastuti dan Rochmadi. 2011. Model Perubahan Volume Keripik Buah Selama Proses Penggorengan Secara Vakum. J.Teknol. dan 
Industri Pangan, vol. XXII No. 1 Th.2011.

Joko Nugroho W.K.,Primawati Y.F, Nursigit Bintoro. 2012. Proses Pengeringan Singkong (Manihot Esculenta Crantz) Parut Dengan Menggunkan Pneumatic Driyer. Denpasar.diakses 31 April 2016.

Martunis.2012. Pengaruh Suhu Dan Lama Pengeringan Terhadap Kuantitas Dan Kualitas Pati Kentang Varietas Granola.Banda Aceh. Jurnal Teknologi dan Industri Pertanian Indonesia Vol. 4, No.3 Diakses 31 Maret 2016.

Muchlis, R.D., Patrick Andreas, Bakti Jos, dan Siswo Sunardiono. 2013. Modifikasi Ubi Kayu dengan Proses Fermentasi Menggunakan Starter lactobacillus casei untuk Produk Pangan. Semarang. Jurnal Teknologi Kimia dan Industri, Vol. 2, No. 4 :137-145. Diakses 18 April 2016.

Noordin Eko Susanto. 2011. Pengaruh tekanan udara terhadap laju perubahan massa pada proses pengeringan dengan metode temperature rendah ( low temperature drying). Universitas negeri Semarang. Diakses 5 desember 2016.

Suriadi I dan Made $R$. 2011.Kesetimbangan Energi Termal Dan EfisiensiTransient Pengering Aliran Alami Memanfaatkan Kombinasi Dua Energi. Jurnal Teknik Industri12.

Susilawati, Siti Nurdjanah, dan Sefanadia Putri. 2008. Karakteristik Sifat Fisik Dan Kimia Ubi Kayu (Manihot
Esculenta) Berdasarkan Lokasi Penanaman Dan Umur Panen Berbeda.Lampung.Jurnal

Teknologi Industry Dan Hasil Pertanian Vol. 12, No. 2. Diakses 6 April 2016.

Varian, Pradipta ., Engkos A. Kosasih. 2014. Pengaruh Laju Aliran, Temperature Dan Kelembaban Udara Terhadap Laju Pengeringan Keeping Singkong. Depok. Diakses 25 Agustus 2016.

Yadollahinia A, Jahangiri M., 2009. Shrinkage of potato slice during drying. Journal of FoodEngineering :94(2009) 5258. 